\title{
РОЛЬ МАТЕРІ У ПОПЕРЕДЖЕННІ ТА ВРЕГУЛЮВАННІ КОНФЛІКТІВ У СІМ’Ӟ
}

\author{
Т. О. Кругла \\ Нікопольський медичний коледж \\ ДВНЗ «Тернопільський державний медичний університет \\ імені І. Я. Горбачевського МОЗ Украӥни»
}

У статті подано розвиток та вибір подружжям стратегій успішного вирішення сімейних конфліктів, вміння налагоджувати ефективні взаємини у сім’і. Досліджено типові установки ролі матері в осіб жіночої статі трьох поколінь: бабусь, матерів і доньок щодо попередження та врегулювання сімейних конфліктів.

\section{FAMILY CONFLICTS AND MOTHER'S ROLE IN THEIR PREVENTION AND ADJUSTMENT}

\author{
T. O. Krugla \\ Nikopol Medical College \\ I. Horbachevsky Ternopil State Medical University
}

\begin{abstract}
The article investigates the typical plant of the role of mother in females of three generations: grandmothers, mothers and daughters, for the prevention and resolution of family conflicts. The purpose of this article is the development and selection of spouses of strategies for the successful solution of family conflicts, as well as the ability to establish effective relationships in the family.
\end{abstract}

Вступ. Незважаючи на велику кількість досліджень та розробок у галузі психології подружньо-сімейних стосунків, останніми роками спостерігається багато негативних явищ у розвитку інституту сім'ї - збільшується кількість розлучень, конфліктів, зрад, непорозумінь, зростає кількість нетрадиційних форм шлюбу та сім'ї, кількість неповних сімей, сімей з нерідними батьками, девальвація сенсу сімейного життя тощо. Під цим кутом зору стає зрозумілим, що сім'я, особливо на початковій стадії їі розвитку, потребує психологічної підтримки та допомоги [1] .

На побутовому рівні можна почути фразу: «Милі сваряться - тільки тішаться». Можливо, що подружні конфлікти можуть мати позитивний характер для конфліктуючих сторін, але якщо подружжя конфліктує щодня це призводить до несумісності, переживань, психічних травм, невротичних розладів, а як наслідок цього - до насильства або розлучення.

Основна частина. Психологія кожної людини чимось істотним відрізняється й проявляється у внутрішньородинних взаємовідносинах людей, особливо у перші місяці й роки існування сім'ї. 3 огляду

(c) Т. О. Кругла, 2018 на таку різницю між членами сім'ї виникають протиріччя, суперечки та навіть конфлікти, які подружжю доводиться вирішувати. Добробут подружнього життя залежить саме від того, яке місце відводиться конфліктам, яким саме чином їх вдається уникнути. Це залежить від уміння кожного з членів подружжя управляти собою, поступатися та йти на компроміс. Досягаються вони не вродженими розумовими здібностями, а внаслідок ретельної роботи людини над собою й, звісно, виховання.

Основоположник сімейного консультування Вірджинія Сатир із цього приводу писала: «Подібно рухам досвідченого моряка, який повинен враховувати форму і розміри прихованої частини айсберга для того, щоб корабель спокійно прийшов до наміченої мети, життя сім'ї залежить від того, наскільки мати розуміє, усвідомлює і враховує почуття, потреби, наміри, спонукання і думки кожного члена сім'і, а вони нерідко приховані саме у підводній частині, закриті від нас повсякденними подіями, звичними словами, діями і вчинками» [2]. Так, у руслі цього висловлювання ми спробуємо дослідити та виявити основні проблеми в житті сім'ї, які, зазвичай «виносять за дужки» сімейні пари. 
Мета дослідження - виявити типові установки ролі матері в осіб жіночої статі трьох поколінь: бабусь, матерів і доньок щодо попередження та вирішення сімейних конфліктів.

Для досягнення мети ми використали методику (опитувальник) PARI Е. Шеффера і Р. Белла «Вивчення сімейних конфліктів та ролі матері у їх врегулюванні» [3]. Особливість опитувальника Е. Шеффера і Р. Белла полягає в тому, що опитуваним пропонують 4 категорії відповідей (А - повністю згодна; а - скоріше згодна, чим ні; 6 - скоріше не згодна, чим згодна; Б - повністю не згодна) на 70 тверджень згрупованих у 14 стратегій по 5 тверджень в кожній.

Відтак, у ході проведення дослідження ми опитали 120 осіб жіночої статі різного віку, серед них було 40 студенток I курсу відділення «Сестринська справа» Житомирського інституту медсестринства, які за віком та сімейним статусом склали досліджувану групу доньок, 80 практикуючих медичних сестер Житомирської області, які були поділені на 2 групи: 40 осіб жінки, в яких $є$ діти, але ще немає внуків (матері), і 40 осіб, в яких є діти і внуки (бабусі).

Аналіз результатів дослідження здійснювали методами варіаційної статистики, реалізованими стандартними пакетами прикладних програм статистики: Excel for Windows Professional ta Statistica [4].
Виходячи з цієї методики, стратегії поведінки матерів, бабусь і доньок визначали за рейтинговими місцями, які їм відвели опитувані. Результати дослідження наведено у таблиці 1. Особливістю таблиці $є$ те, що стратегії розташовані у порядку зростання за принципом найбільших відхилень. Партнерські відносини як найбільш доцільні і прийнятні на перше рейтингове місце віднесли дорослі заміжні жінки, які мають дітей і внуків. Дорослі заміжні жінки, які мають дітей, але ще не мають внуків, стратегію партнерських відносин у шлюбі поставили на друге місце, а перше місце відвели відчуттю байдужості чоловіка до проблем сім'і. Незаміжні дівчата-підлітки віком 15-17 років, які не мають дітей, на перше місце у рейтингу поставили самопожертву, у той час як стратегії партнерських відносин вони відвели лише 7 рейтингове місце. Окрім завищеного суб'єктивного відчуття байдужості чоловіка до проблем сім'ї дорослі заміжні жінки продемонстрували такі неприйнятні стратегії поведінки в сім'ї, як схильність до конфліктної поведінки та до пригнічення волі інших членів сім'і.

Для наочності із блоків зобразимо піраміду стратегій, яку продемонстрували нам опитані. На вершину піраміди помістимо блок партнерських відносин у сім'і. Цей найменший блок становитиме одну будівельну одиницю. Відповідно, інші блоки будуть на одну одиницю більші в міру їхнього наближення до основи. Найнижчі

Таблиця 1. Стратегії поведінки матерів, бабусь і доньок

\begin{tabular}{|l|c|c|c|c|c|c|c|c|}
\hline \multirow{2}{*}{ Назва стратегії } & \multicolumn{2}{|c|}{ Доньки } & \multicolumn{2}{|c|}{ Матері } & \multicolumn{2}{c|}{ Бабусі } & \multicolumn{2}{c|}{ Разом } \\
\cline { 2 - 9 } & $\begin{array}{c}\text { абс. } \\
\text { к-сть }\end{array}$ & $\begin{array}{c}\text { рей- } \\
\text { тинг }\end{array}$ & $\begin{array}{c}\text { абс. } \\
\text { к-сть }\end{array}$ & $\begin{array}{c}\text { рей- } \\
\text { тинг }\end{array}$ & $\begin{array}{c}\text { абс. } \\
\text { к-сть }\end{array}$ & $\begin{array}{c}\text { рей- } \\
\text { тинг }\end{array}$ & $\begin{array}{c}\text { абс. } \\
\text { к-сть }\end{array}$ & $\begin{array}{c}\text { рей- } \\
\text { тинг }\end{array}$ \\
\hline Пригнічення волі інших членів сім'ї & 55 & 13 & 93 & $7-8$ & 130 & $4-5$ & 278 & 8 \\
\hline Схильність до конфліктної поведінки & 62 & 11 & 113 & 3 & 126 & 7 & 301 & 6 \\
\hline $\begin{array}{l}\text { Схильність до домінування над чле- } \\
\text { нами сім'і }\end{array}$ & 60 & 12 & 79 & 13 & 107 & 11 & 216 & 13 \\
\hline Незадоволеність у ролі господині & 75 & 8 & 84 & $10-11$ & 93 & 12 & 252 & 12 \\
\hline $\begin{array}{l}\text { Дратівливість при спілкуванні з чле- } \\
\text { нами сім'і }\end{array}$ & 65 & 10 & 84 & $10-11$ & 111 & $9-10$ & 260 & 10 \\
\hline Надмірна строгість до членів сім'ї & 80 & 5 & 82 & 12 & 113 & 8 & 275 & 9 \\
\hline $\begin{array}{l}\text { Схильність до партнерських сімейних } \\
\text { відносин }\end{array}$ & 78 & 7 & 118 & 2 & 156 & 1 & 352 & 1 \\
\hline Побоювання образити членів сім'ї & 79 & 6 & 105 & 4 & 130 & $4-5$ & 314 & 4 \\
\hline $\begin{array}{l}\text { Надмірна турбота (опіка) над членами } \\
\text { сім'ї }\end{array}$ & 85 & 2 & 93 & $7-8$ & 111 & $9-10$ & 289 & 7 \\
\hline Надмірна залежність від проблем сім'ї & 81 & 4 & 87 & 9 & 135 & 2 & 303 & 5 \\
\hline $\begin{array}{l}\text { Відчуття байдужості чоловіка до проб- } \\
\text { лем сім'ї }\end{array}$ & 83 & 3 & 122 & 1 & 134 & 3 & 339 & 2 \\
\hline Схильність до самопожертви & 87 & 1 & 102 & 5 & 129 & 6 & 318 & 3 \\
\hline Уникання конфліктів за будь-яку ціну & 71 & 9 & 98 & 6 & 85 & 13 & 254 & 11 \\
\hline
\end{tabular}


блоки, які лежать з обох сторін в основі піраміди «Уникання конфліктів за будь-яку ціну» і «Пригнічення волі інших членів сім'і» - найбільші. Чим ближче до вершини піраміди, тим доцільніша стратегія. Чим ближче до основи, тим стратегія менш прийнятна. Умовну піраміду прийнятних сімейних відносин зображено на рис. 1.
На думку Т. О. Попович, конфліктнішими у сімейному житті виступають дружини [5]. Вони є ініціаторами суперечок здебільшого у матеріальній сфері, що характеризує ставлення до грошей загалом, способів їх заробітку та витрачання зокрема. На цьому ж таки рівні знаходиться і сфера прояву ревнощів один до

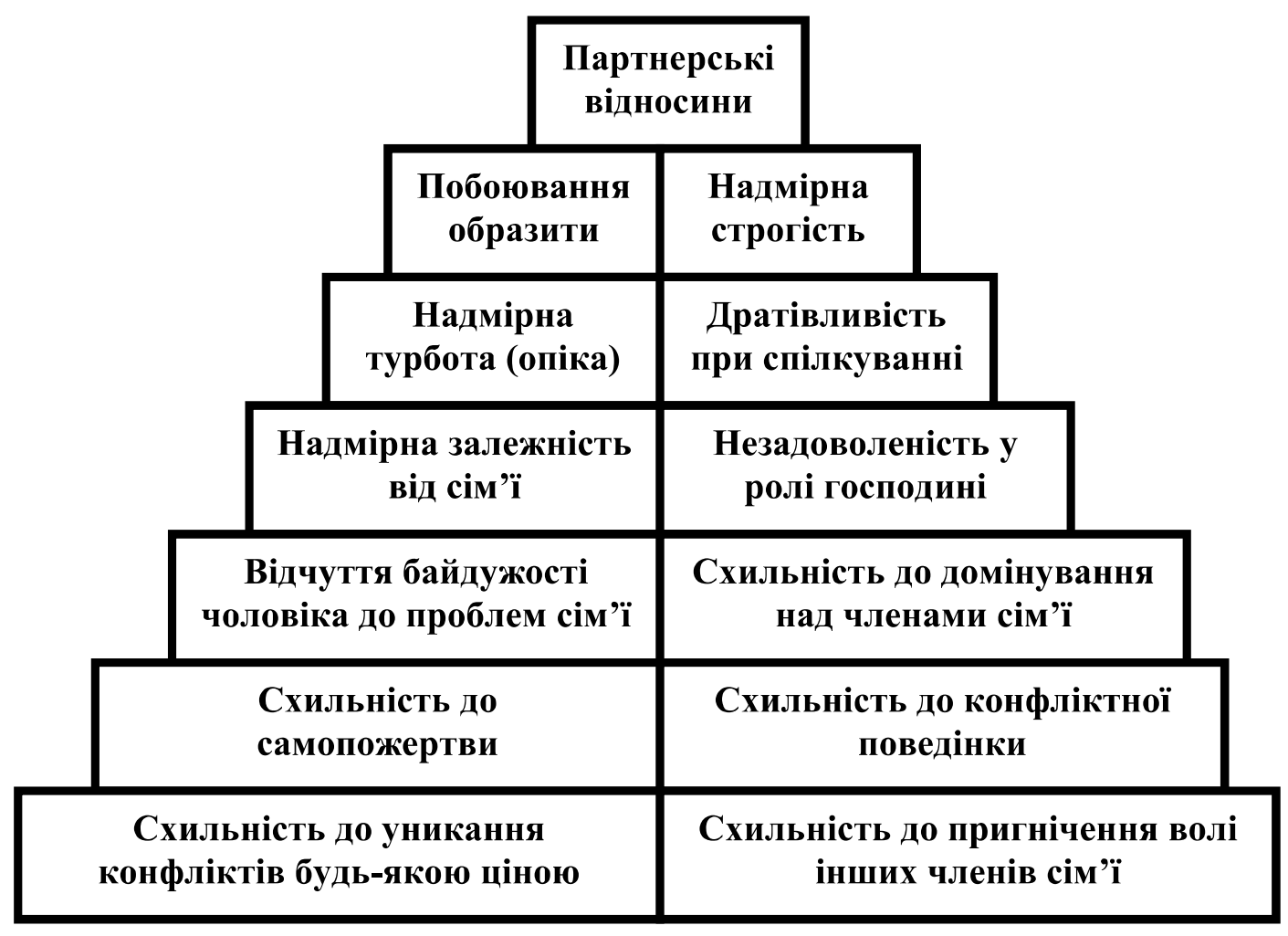

Рис. 1. Піраміда найдоцільніших стратегій жінки і матері у сімейних відносинах.

одного, сфера домінування та сфера прагнення до автономії [5]. Непорозуміння у цих сферах спричинені тим, що власна незалежність, особистий простір, індивідуальність у думках, поглядах і вчинках $є$ досить важливими для членів подружжя (особливо молодих, які ще не дуже звикли до спільного сімейного «тандему»). Вони не розуміють думки один одного з півслова, не вміють розпізнавати побажання партнера, часто не розуміють зміст дій чи вчинків своєї пари [5]. Виховання дітей і виконання своїх батьківськоматеринських обов'язків також більше хвилюють жінок. Йдеться також про низький рівень залучення чоловіків-батьків до виховання малолітніх дітей [5].

Експериментально доведено, що існують розбіжності у виборі тієї чи іншої стратегії вирішення сімейного конфлікту. В цілому жінки проявляють більше терпимості і тяжіють до компромісного стилю врегулювання протиріч [5].

Основними причинами конфліктів $\epsilon$ нерозуміння і неврахування вікових особливостей та індивіду- альних потреб, емоційних і фізичних можливостей, невідповідність вимог й очікувань можливостям і потребам особистості, загострення негативних поведінкових проявів суб'єктів взаємодії. Але, оскільки сімейні конфлікти неминучі, їхня роль у житті сім'ї позитивна (за умови адекватного і своєчасного вирішення).

Відповідно до результатів опитування вибудовується своєрідна піраміда рейтингових позицій щодо стратегій побудови сімейних відносин (рис. 2).

Загалом піраміда має майже правильну форму. На її вершині - найменший блок «Партнерські відносини». В основі зліва - найбільший «Уникання конфліктів за будь-яку ціну». 3 правої сторони в основі також лежить досить великий блок «Схильність до домінувння». Однак, друга і третя позиції зверху з обох сторін перевантажені великими блоками, місце яких ближче до основи. Як бачимо, така піраміда сімейних стратегій хоча і дещо деформована, але досить стійка.

Виходячи з цього, пропонується чимало практичних рекомендацій щодо попередження конфлікту і

50 ISSN 2411-1597. МЕДСЕСТРИНСТВО. 2018. № 1 


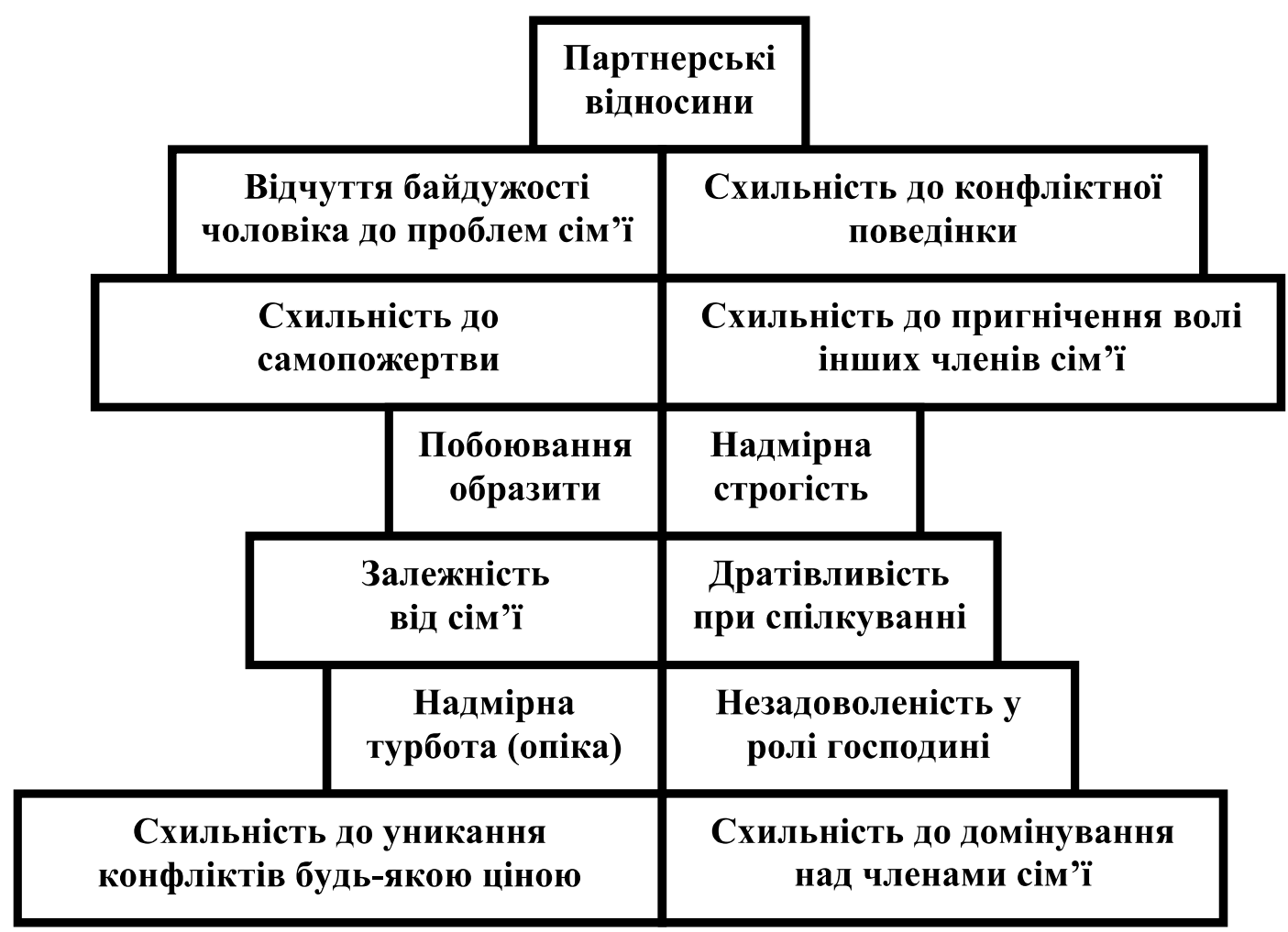

Рис. 2. Рейтингові місця стратегій, які обрали опитувані.

стосовно його профілактики чи послаблення. При цьому вибір способів і методів подолання конфліктів залежить як від об'єктивної ситуації, психічного стану опонентів, так і від спрямованості конфлікту, тобто чи сприятиме він глибшому розумінню проблеми, а отже, й розвитку елементів кооперативної взаємодії всередині конфлікту, чи навпаки: призведе до розхитування й неузгодженості взаємодії [6].

Таким чином, результатом нашого дослідження можуть бути рекомендації щодо вирішення сімейних конфліктів, спрямованих на поліпшення сімейних взаємин:

- Якщо виникає конфлікт, то не піддавайтеся емоціям і не поспішайте його форсувати (конфліктуйте не поспішаючи).

- Аналізуючи конфліктну ситуацію, шукайте причину і не «зациклюйтесь» на самому факті конфлікту.

- Аналізуйте всі «позитивні» і «негативні» моменти тих чи інших варіантів розвитку конфлікту.

- Не прагніть «зам'яти» конфлікт, а доведіть його до логічного кінця (якщо, звичайно, переконані у своїй правоті і твердо вірите, що вас зрозуміють і підтримають у колективі).

- Не конфліктуйте по дрібницях!

- Не ставтесь до інших так, як ви не хотіли би, щоб вони ставились до Вас. Суть даного правила полягає в тому, що важливо завжди, а особливо в ситуації пошуку виходу з конфлікту, вміти зберегти в собі об'єктивність і бачити в конфліктуючому насамперед людину.

- Дайте людям відчути свою значимість. Не загострюйте увагу на недоліках супротивників, а знайдіть у них ті якості, ті вчинки, що характеризують їх із позитивної сторони. Визнаючи достоїнства своїх супротивників, ви вже цим самим робите крок назустріч до примирення і розв'язання конфлікту.

- Хто робить перший крок до примирення, той виграє. При цьому використовуйте добрі слова, що додає нам сили, а іноді і розв'язує конфліктну ситуацію.

Підводячи підсумок ми повинні розуміти, що вирішення конфліктної ситуації має бути спокійним, гуманним, етичним та максимально відповідати очікуванням обох сторін.

Висновки. Проведені результати цього дослідження свідчать, що дорослі заміжні жінки (опитувані медичні сестри) переоцінюють роль чоловіка в сім'і, вони ставлять перед ним завищені вимоги, демонструючи при цьому схильність до конфліктів і пригнічення волі інших членів сім'і. За такого поєднання стратегій конфлікти в сім'ї неминучі. Тому, їм необхідно більш толерантно ставитись до інших членів сім'ї та беззастережно відмовитись від прагнення домінувати в сім'ї. 
Дівчатам-підліткам навпаки необхідно підвищувати самооцінку для того, щоб партнерські відносини в сім'і прийшли на зміну схильності до самопожертви.

Разом з тим, результати опитування дозволяють стверджувати, що в подружніх відносинах найважливішим є взаєморозуміння, повага один до одного, вміння поступатися та висловлювати власну думку

\section{СПИСОК ЛІТЕРАТУРИ}

1. Гриненко А. М. Конфліктологія : навч. посіб. / А. М. Гриненко, В. М. Петюх. - К. : КНЕУ, 2003. - 315 с.

2. Сатир В. Как строить себя и свою семью : пер. с англ. / В. Сатир. - М. : Педагогика. - Пресс, 1992. - 190 с.

3. Райгородский Д. Я. Практическая психодиагностика. Методики и тесты :учебное пособие/Д. Я. Райгородский. Самара : Издательский Дом «БАХРАХ», 1998. - 672 с.

4. Тебайкина Н. И. ПРОГРАMMA «STATISTICA» : методические указания к выполнению лабораторных работ / Н. И. Тебайкина. - Екатеринбург : гоУ ВПО угтУ-УПИ, 2006. - 44 c. на ті чи інші питання. Звісно, що безконфліктних ситуацій не буває, але все ж таки в такі моменти необхідно пам'ятати про те, що поєднало подружжя. Це насамперед - кохання, яке має дарувати людям щастя, а не образи, сварки, нервові та психологічні розлади.

5. Попович (Гісем) Т. О. Гендерний аспект вибору молодими людьми стратегій вирішення сімейних конфліктів / Т. О. Попович (Гісем) // Актуальні проблеми психології : 3б. наук. пр. Інституту психології імені Г. С. Костюка НАПН України. - К., 2012. - Т. 8. Психологічна теорія і технологія навчання. - Вип. 8. - С. 99-115.

6. Аклаев А. Р. Этнополитическая конфликтология: анализ и менеджмент / А. Р. Аклаев . - М. : Дело, 2005. - 472 с.

7. Шатило В. Й. Соціальні чинники та психологічні передумови виникнення сімейних конфліктів / В. Й. Шатило // Сімейна медицина. - 2013. - № 5. C. $118-125$. 